\title{
Application of E-Learning System in The World of Education
}

\author{
Senny Luckyardi', L. Rahman ${ }^{2}$ \\ ${ }^{1}$ Departemen Manajemen, Universitas Komputer Indonesia, Indonesia \\ ${ }^{2}$ Departemen Ilmu Komunikasi, Universitas Komputer Indonesia, Indonesia \\ Jl. Dipati Ukur No.112-116, Lebakgede, Kecamatan Coblong, Kota Bandung, Jawa Barat 40132 \\ *Corresponding Author: *timkonferensi4@gmail.com
}

\begin{abstract}
INTISARI
Aplikasi teknologi e-learning pada dunia pendidikan harus mengacu pada peningkatan daya saing mahasiswa yang memiliki hard skill dan soft skill. Salah satu indikatornya adalah mahasiswa dituntut untuk memiliki pemahaman konsep yang komprehensif melalui pelaksanaan e-learning. Tujuan dari penelitian ini adalah untuk mengetahui efek positif dari sistem e-learning pada peningkatan pemahaman konsep mahasiswa dan peningkatan kognitif mahasiswa, serta membandingkan e-learning dengan sistem pembelajaran lama. Pemahaman konsep dapat ditunjukan dengan pengukuran Kompetensi dasar atau Basic skills (BS), Kompetensi yang diperoleh atau Acquired Skills (AS), Prestasi pada perkuliahan/College Accomplishment (CA), and Kemampuan manajemen waktu/Time management (TM). Studi kasus dilakukan di Universitas Komputer Indonesia yang merupakan salah satu perguruan tinggi swasta di Indonesia. Penelitian ini dilakukan dengan metode kuantitatif dengan analisis regresi linear sederhana. Pengumpulan data dilakukan dengan menyebarkan kuesioner pada 261 responden. Pengambilan data dan informasi dari Learning Management System (LMS), wawancara dengan divisi terkait dan studi literatur dilakukan untuk melengkapi data. Hasil dari penelitian ini adalah bahwa e-learning dapat meningkatkan pemahaman konsep mahasiswa, kemampuan kognitif siswa dan daya saing mahasiswa karena lebih mudah untuk mengakses kata-kata, powerpoint, html atau PDF dalam aplikasi LMS. Kesimpulannya adalah bahwa e-learning dapat meningkatkan pemahaman konsep mahasiswa dan dapat digunakan sebagai inovasi pembelajaran yang dapat membantu dosen dan siswa menggunakan Sistem Manajemen Pembelajaran Perangkat Lunak. Hasil penelitian ini diharapkan dapat memberikan input dalam pembangunan teknologi e-learning di universitas.
\end{abstract}

Kata kunci: E-Learning, Aplikasi, Sistem Pembelajaran, Edukasi.

\begin{abstract}
The application of e-learning technology in education must refer to increasing the competitiveness of students who have hard skills and soft skills. One of the indicators is that students are required to have a comprehensive understanding of concepts through the implementation of e-learning. The purpose of this study was to determine the positive effect of the e-learning system on improving student conceptual understanding and cognitive enhancement of students, as well as comparing e-learning with the old learning system. Concept understanding can be demonstrated by measuring basic skills (BS), acquired competencies or Acquired Skills (AS), College Accomplishment (CA), and Time management (TM) abilities. The case study was conducted at the Indonesian Computer University, which is one of the private universities in Indonesia. This research was conducted using quantitative methods with simple linear regression analysis. Data collection was carried out by distributing questionnaires to 261 respondents. Retrieval of data and information from the Learning Management System (LMS), interviews with related divisions and literature studies were carried out to complement the data. The results of this study are that e-learning can improve student understanding of concepts, student cognitive abilities and student competitiveness because it is easier to access words, powerpoint, html or PDF in the LMS application. The conclusion is that e-learning can improve student understanding of concepts and can be used as a learning innovation that can help lecturers and students use the Software Learning Management System. The results of this study are expected to provide input in the development of e-learning technology at universities.
\end{abstract}

Keywords: E-Learning, Application, Learning System, Education. 


\section{INTRODUCTION}

The development of technology helps human in many aspects, one of it is that the change of education system from conventional learning system to the digital form [1]. Conventional learning system is a traditional way to learn in school where we need to go to school for doing the study and the time provided in the classroom is also limited. Therefore, with the limited of time, some students might be cannot catching up with the topics or subjects. In addition, the solution that can be taken from these problems are E-learning [2]. With the use of E-learning, it is expected to get a positive response from the community. E-learning has also become an important thing in education field. Elearning helps education field to be better as become more advanced and developing. The quality of E-learning must be maintained and further improved so that the initial goal of education can still be achieved well. The method of implementing E-learning has been practiced by all universities, with its advantages, lecturers can interact with students outside of class schedules. Students also can download materials or references given by lecturers through E-learning. This is useful also for students because references from journals will help them to get new insights and improve the ability of students [3].

E-learning has several advantages including students being able to share information and be able to access learning materials at any time as well as the evaluation or exam that can measure students' understanding. With these conditions, students are expected to strengthen the understanding concept of the learning material. Elearning can train students' independence and experience when doing electronic learning [4]. LMS is a software system that accommodates teaching and learning processes from conventional to digital concepts for all types of activities such as administration, documentation, reports programs, classrooms, and training content that are all accessed by the internet. Content or teaching materials can be in the form of Multimedia-based Content or interactive multimedia content. Elearning that can improve students cognitive abilities is e-learning which has a high level of user interactivity, which in addition to present learning material in words, power point, html or PDF format. There is also a virtual class that can accommodate teachers and students to be able to interact and create virtual laboratories by inserting media in the form of animated images so that the teacher can explain through the media [5]. In addition, technology application, in this term e-learning is the source of student's concept mastering, competitive advantage and organizational learning which relate to system adaption or change [6]. Therefore, the student's concept mastering (SCA) has been predicted to have strong relations to e-learning application (IT based university/ITU) and therefore become an interesting issue to be researched.

The aims of this study is to determine the benefits of e-learning systems on improving student's concept mastering and comparing elearning with old learning system, and this study used quantitative methods with simple linear regression analysis

\section{METHOD}

The method used in this research was case study conducted at Universitas Komputer Indonesia, which is one of the private universities in Indonesia. This research was conducted using quantitative methods with simple linear regression analysis. Data collection was carried out by distributing questionnaires to 261 respondents in 12 April- 15 May 2020. Retrieval of data and information from the Learning Management System (LMS), interviews with related divisions and literature studies were carried out to complement the data.

\section{RESULTS AND DISCUSSION}

Describe One of the most important thing is internet. The internet is used to find informationa, can be used as a communication tool, and much more. There are so many benefits gained from using the internet, one of them is in the education field. At present day, there is an online education or digital education called E-learning. E-learning is online distance learning that utilizes computer technology, computer networks, and most importantly is the internet. By using the E-learning system, students can get more material or references from the lecturers through the application. Besides, it has 
been proven that e-learning is more effective for the students because they do not need to come to the class meeting and can be accessed anywhere. therefore, learning time becomes more effective and efficient when using the E-learning method. Indonesia is ranked eighth in using online distance learning, called E-learning, with a growth rate around 25\% (See Figure 1).

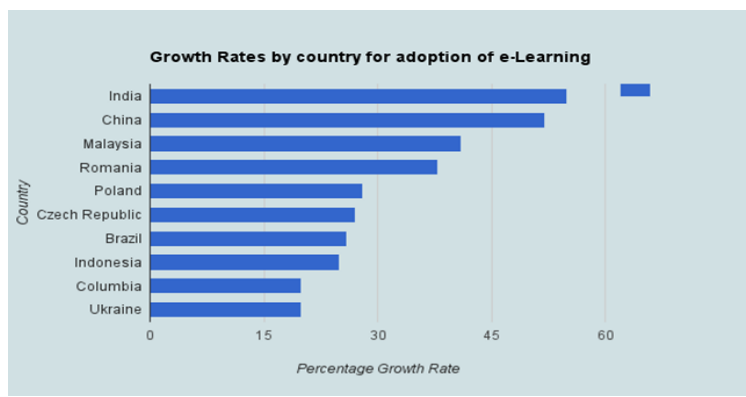

Figure 1. Growth Rates by Country for Adoption of E-learning Source: http://blog.stratbeans.com/how-e-learning-tools-arechanging-the-way-learning-takes-place/, on 22nd February 2020

The validation test was performed on the LMS software to get an actual data. The results show that the LMS software obtained a percentage of $89.81 \%$. The results of the expert validation can be concluded that the LMS software qualifies as a companion teaching material for students. LMS software is categorized as a valid application for elearning. Besides containing the main material, which is optical devices, the LMS software is also equipped with instructions use, competencies achieved, practice questions, online assignment questions, supporting enrichment materials, related learning resource links, and discussion forums. LMS software can also be accessed repeatedly and provide new experiences for students. LMS users will get new experiences that are different from conventional learning methods [6]. Student learning outcomes using LMS software were tested using posttest. Based on the posttest results, it was found that the increase is in the average of students. The average posttest score of students is 76.93 while the average pretest is $47.61 \%$. The result shows an increase in students' understanding of the concepts after using LMS software. This is in accordance with [7], which states the function of LMS is to add insight and help students' understanding. Currently, Indonesia is a country that has a positive trend in the online education industry (e-learning) and ranked 8th in worldwide based on the total of e-learning market each year, which is $25 \%$. Indonesia is also one of the countries that recorded a total growth of e-learning market that exceeds the average in Asian countries and throughout the world each year. If the implementation of E-learning in Indonesia can continue to develop, it is possible that Indonesia will move up to a higher level to shift other large countries. This is one of a great achievements because education is also one of the important factors for the country (see Figure 2).

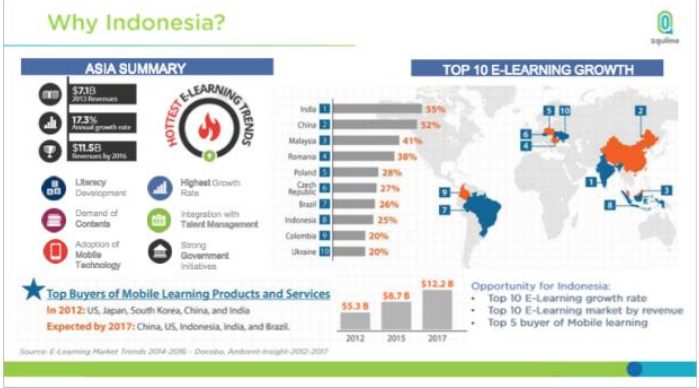

Figure 2. Indonesia as one of Top 10 e-learning Growth Source: http://humorpoin.blogspot.com/2017/07/trenbelajar-online-di-indonesia.html, on 22nd February 2020

Asia shows the most interesting trends which include literacy development, demand of contents, adoption of technology, highest growth rate, integration with talent management, and strong government initiatives. Moreover, Indonesia also has a promising opportunities in 2017 due to an increase in e-learning market that reach USD 12.2 billion. The opportunity to grow e-learning business in Indonesia is promising, it can be seen by the increasing number of requests for e-learning needs each year. E-learning has become a promising business, one of a e-learning bussines is Ruangguru. Therefore, because of the content, Ruangguru is very popular in Indonesia. E-learning makes learning models from conventional to digital. Teachers can provide the subject for students, taught them, managed the activities of students using attendance online, gathering assignments becomes easier and more practical, and others. Sometimes, instructors can also arrange and plan online chats with students, announce information, and also provide input and advice to their students [8]. The more detailed benefits of using e-learning can be seen from 2 sides, including:

1.Students: E-learning enables the development of high learning flexibility. Students can easily access learning material anytime and anywhere as well as can communicate with lecturers at any time. Thus, students are better able to learn the materials provided by lecturers better as they have more time and more flexible. 
2.Lecturers: (1) It is easy to establish the learning material; (2) More able to develop themselves or also have more free time to do research in order to increase their insight; (3) can monitors student learning activities thorougly. Lecturers can also find out when students learn, what topics are being discussed and studied, how many times certain topics are re-studied by students; (4) can check whether students have done practice questions after studying certain topics; and (5) Checking student answers and notifying the results directly to students.

There are several terms from E-learning, namely web-based learning, online learning, distributed learning, and internet-based learning [9]. Then there is also a term called Blended Learning. It is an approach that combines the Elearning system with a training for example such as lectures that are equipped with online tutorials. The advantage of blended learning is the increased accessibility to information and focuses on the ability of the student. As we all know that internet technology can spread various kinds of digital content widely to many users, anytime and anywhere [10]. Therefore, it will help the training process. Besides, another advantage is that elearning can potentially be large and more revolutionary both for the lecturers and the students [11].

The use of E-learning shows the flexibility to complete tasks wherever and whenever, providing comfort, and making users responsible and competent. Thus, the use of e-learning also affects greatly on student motivation. It is said that the use of E-learning is higher than using conventional learning methods [12].

Based on the communication method, we can identify four different generations namely:

\section{First Generation}

In 1837, in England, Isaac Pitman began making short courses with correspondence. The short course was successful that in 1843 he founded the "Phonographical Correspondence Society". Then in 1951, Scuola Radio Elettra in Italy also established a correspondence course.

\section{Second Generation}

Around 1960-1990 a training course was established, in addition to the traditional postal services that had emerged, new media emerged such as audio cassettes, video cassettes, and CD-
ROMs. In this era, advertising is more accesible for students through television broadcasts.

\section{Third Generation}

In the 1990s, those years of education became successful because of internet existence. In this era, using Computer diffusion becomes one of the most important tools that support online training. Software also appeared specifically devoted to management and automatic control to oversee the independent training process.

\section{The Fourth Generation}

Many types of learning are develop to the global network. Because of the internet, it has become one of the advantages of the distance learning. The Fourth Generation grows and develops in parallel with the evolution of the Web, making it more interactive and collaborative.

This era is the most important time for Elearning training because distance education is considered as a trusted concept for highly successful training. This is the beginning of how users begin to approach and use forms of distance education (See Figure 3).

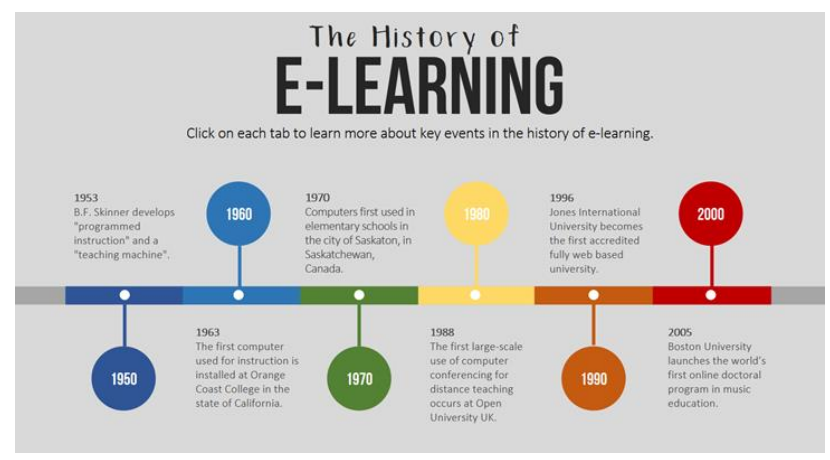

Figure 3. The History of E-Learning

Source: https://community.articulate.com/download/historyof-elearning, on 22nd February 2020

Table 1. Result of Validity and Reliability Test

\begin{tabular}{lll}
\hline Variables & Indicators & Validity \\
\hline $\begin{array}{l}\text { IT-based University (ITU) } \\
\text { Which apply e-learning }\end{array}$ & E-Learning & 0.914 \\
& & \\
\hline Student's concept & Basic Skills & 0.917 \\
mastering (SCA) & Acquired Skills & 0.924 \\
& College Accomplishment & 0.909 \\
& Time Management & 0.872 \\
\hline
\end{tabular}

Table 1 showed that all statement were stated valid and reliable. Table 2 showed that Elearning as one of the ITU indicators has influenced significantly on SCA that covers BS, AS, CA and TM. The easiness to find literatures in online library in 
ITU can enrich the knowledge of the student, thus it can increase SCA's in basic skills, acquired skills, college achievement, and time management as well.

Table 2. Result of Regression Test

\begin{tabular}{|c|c|c|c|c|c|c|}
\hline Model & & $\begin{array}{l}\text { Unstandardizec } \\
\text { Coefficients }\end{array}$ & & \begin{tabular}{|c|} 
Standardized \\
Coefficients
\end{tabular} & $t$ & Sig. \\
\hline & & B & Std. Error & Beta & & \\
\hline \multirow{2}{*}{1} & (Constant) & .146 & 1.773 & & .082 & .934 \\
\hline & ITU & 1.184 & .064 & .782 & 18.384 & .000 \\
\hline
\end{tabular}

Regression equation: $\mathrm{Y}=0.146+1.184 \mathrm{X} 1$

T count 18.384

T table 1.971

$\mathrm{T}$ count $>\mathrm{T}$ table, the conclusion is ITU has a strong influence toward SCA

However, there is also a negative affects from this e-learning system. As E-learning makes it easier for users to access the information, but there are a lot of people who are lazy and some people think it is not effective. There are also reasons that Elearning is not effective. One of it is because we do not meet the lecturers directly. Even though Indonesia is ranked eighth in the use of E-learning systems, in reality there are still many people who are not yet interested in this method. Some people prefer to use the conventional learning method. It is because some people needs time to adjust themselves to the e-learning system [13].

Therefore, further promotions are needed so people can adjust to the technology and do not need to use the conventional method anymore. Especially for students in this current era, their generation is required to understand the E-learning system. Elearning becomes one of a supporting tool as it has a lot of advantages for them [14]. This is the difference between E-learning and conventional learning methods. It can be seen that both have the advantages and disadvantages, depending on how we respond (see Figure 4).

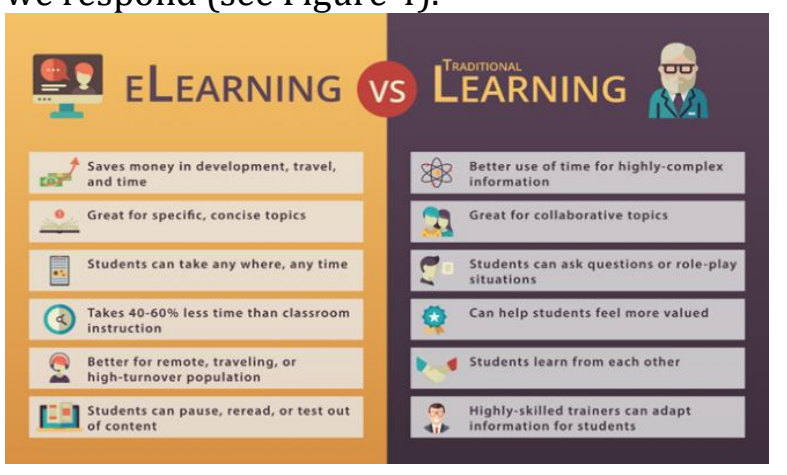

Figure 4. E-Learning VS Pembelajaran Tradisional Source: https://thewideclass.com/online-face-to-facelearning-comparison/, on 22nd February 2020
The challenge of using E-learning is that we need to improve the quality of E-learning. Elearning that rely on graphics or animations that are too flashy will disturb students. When doing the learning process, each person has a different learning style. Some focus on learning by watching or watching Figures, there is also a focus on learning by listening to songs and others. One thing that is lacking from conventional learning media itself is the high cost compared to E-learning, this is one of the factors that emerges obstacles and makes people prefer using E-learning methods that are more modern and practical. Usually people who are still using conventional media are parents who do not understand about technology. However, the current E-learning market is not only for parents but also for their children or students as they are the one who will use the E-learning system.

\section{CONCLUSION}

The conclusion is that e-learning can be used as a learning innovation. By using the Software Learning Management System more effectively can improve the students' concept understanding. It is because the more intensive E-learning is used and utilized, the quality of user will increase. Utilization of using E-learning will indirectly improve learning outcomes too. The purpose of E-learning is to expand the education to the wider community as well as to improve the quality of learning.

\section{REFERENCES}

[1] E.S. Soegoto, \& C. Chandra. Building Concept of High School Information Technology Based. In IOP Conference Series: Materials Science and Engineering, 407(1), pp. 012022. 2018.

[2] I. Jung. The dimensions of e-learning quality: from the learner's perspective. Educational Technology Research and Development, 59(4), pp.445-464. 2011.

[3] S. Kumar, A.K. Gankotiya, \& K. Dutta. A comparative study of moodle with other elearning systems. In 2011 3rd International Conference on Electronics Computer Technology, 5, pp.414-418. 2011.

[4] A. T. Wibowo, I. Akhlis, S. E. Nugroho. Pengembangan LMS (Learning Management System) Berbasis Web untuk Mengukur Pemahaman Konsep dan Karakter Siswa, Scientific Journal of Informatics, 1(2),pp. 127137. 2014. 
[5] Turino, Y. Purwanto, dan A. Soeleman. ELearning Bahasa Inggris Berbasis web. Jurnal Teknologi Informasi. 5(2), pp.726-739. 2009.

[6] Moingeon, B., \& Edmondson, A. (Eds.). (1996). Organizational learning and competitive advantage. Sage.

[7] M.R. Karim, dan Y. Hashim. The Experience of the E-Learning Implementation atthe Universiti Pendidikan Sultan Idris, Malaysia. Malaysian Online Journal of Instructional Technology (MOJIT). 1(1), pp.50-59. available online at www.library.oum.edu. 2004.

[7] Tafiardi. Meningkatkan Mutu Pendidikan Melalui E-Learning. Jurnal Pendidikan Penabur. 4(4), pp.85-97. 2005.

[8] V. Arkorful, \& N. Abaidoo. The role of elearning, advantages and disadvantages of its adoption in higher education. International Journal of Instructional Technology and Distance Learning, 12(1), pp.29-42. 2015.

[9] E. Karwati. Pengaruh Pembelajaran Elektronik (E-Learning) Terhadap Mutu Belajar Mahasiswa. Jurnal Penelitian Komunikasi, 17(1), pp.41-54. 2014.

[10] J.F. Moloney, \& B. Oakley. Scaling online education: Increasing access to higher education. Journal of Asynchronous Learning Networks, 14(1), pp.55-70. 2010.

[11] J. Poon. Blended learning: An institutional approach for enhancing students' learning experiences. Journal of online learning and teaching, 9(2), pp.271-288. 2013.

[12] M. G. Domingo, \& A. B. Garganté. Exploring the use of educational technology in primary education: Teachers' perception of mobile technology learning impacts and applications' use in the classroom. Computers in Human Behavior, 56, pp.21-28. 2016.

[13]J. Stoltenkamp, \& O. A. Kasuto. E-Learning change management and communication strategies within a HEI in a developing country: Institutional organisational cultural change at the University of the Western Cape. Education and Information Technologies, 16(1),pp. 4154. 2011.

[14]E. Ansong, S. L. Boateng, \& R. Boateng. Determinants of e-learning adoption in universities: Evidence from a developing country. Journal of Educational Technology Systems, 46(1), pp.30-60. 2017. 